\title{
O PENSAMENTO HEIDEGGERIANO NA OBRA DE ÉRIC DARDEL: A CONSTRUÇÃO DE UMA ONTOLOGIA DA GEOGRAFIA COMO CIÊNCIA EXISTENCIAL ${ }^{1}$
}

\author{
HEIDEGGER'S THOUGHT IN THE ÉRIC DARDEL'S WORK: \\ CONSTRUCTION OF AN ONTOLOGY OF GEOGRAPHY AS AN \\ EXISTENTIAL SCIENCE
}

\section{EL PENSAMIENTO DE HEIDEGGER EN LA OBRA DE ÉRIC DARDEL: LA CONSTRUCCIÓN DE UNA ONTOLOGÍA DE LA GEOGRAFÍA COMO UNA CIENCIA EXISTENCIAL}

\author{
Priscila Marchiori Dal Gallo \\ Graduação em geografia pela Universidade Estadual de Campinas (Unicamp). Mestre em geografia \\ pela Unicamp. \\ Rua Pedro Zaccaria, 1300. Cidade universitária. CEP: 13484-350 - Limeira, SP - Brasil \\ E.mail: priscilamgallo@yahoo.com.br
}

\section{Eduardo Marandola Junior}

Doutorado em Geografia pelo Instituto de Geociências da Universidade Estadual de Campinas. Professor (MS3) da Faculdade de Ciências Aplicadas (FCA) da Unicamp (Campus de Limeira). Rua Pedro Zaccaria, 1300. Cidade universitária. CEP: 13484-350 - Limeira, SP - Brasil E.mail: eduardo.marandola@fca.unicamp.br

\section{RESUMO}

O O Homem e a Terra de Éric Dardel surge em uma época na qual os paradigmas da ciência moderna eram predominantes na comunidade geográfica, de modo que a obra permaneceu marginal desde 1952 (ano de lançamento) até os anos 1970 quando geógrafos anglo-saxões a resgatam e a utilizam para reformulações epistemológicas. Contudo, a proposta de Dardel de uma geografia fenomenológica não foi amplamente explorada, a busca do autor por uma ontologia geográfica foi um dos seus esforços pouco explorado, bem como, os referenciais filosóficos que o alicerçam. No presente texto exploramos um desses referenciais, propondo mapear os desdobramentos do pensamento de Martin Heidegger na concepção da Geografia de Dardel como uma ciência existencial, explorando, sobretudo, sua leitura da concepção heideggeriana de terra buscando resgatála e reconhecê-la como um solo fundamental de todo conhecimento.

Palavras-chave: Embate Terra-mundo; epistemologia; ciência existencial; Geografia fenomenológica; Geografia humanista

\footnotetext{
Este texto foi realizado no âmbito do Grupo de Pesquisa Geografia Humanista Cultural (GHUM).
} 


\section{ABSTRACT}

The The Man and the Earth of Éric Dardel appears at a time in which the paradigms of modern science were predominant in the geographic community, remaining marginal since 1952 (year of release) until years 1970 when Anglo-Saxon geographers resume that work and use it for epistemological reformulations. However, the proposal of a phenomenological geography by Dardel was not been widely explored, his search for a geographic ontology was one of his efforts that has little explored, as well as, the philosophical frameworks that supported him. In this paper we explore one of these frameworks, proposing map the ramifications of the thought of Martin Heidegger in Dardel's conception of Geography as a existential science, exploring, over all, his reading of the heideggerian conception of earth seeking to resume and recognize it as the ground of all knowledge.

Keywords: Strife Earth-world; epistemology; existential science; phenomenological Geography; humanistic Geography

\section{RESUMEN}

Le El hombre y la Tierra de Éric Dardel llega en un momento en que los paradigmas de la ciencia moderna eran predominante en la comunidad geográfica, por lo que la obra permanece marginal desde 1952 (año de su lanzamiento) hasta la década de 1970 cuando geógrafos anglosajones la rescatan e la utilizan para sus reformulaciones epistemológicas. Pero, la propuesta de Dardel de una geografía fenomenológica no ha sido ampliamente explorada, su búsqueda por la ontología geográfica fue uno de sus esfuerzos poco explorado, así como los referenciales filosóficos que o sustentan. En este artículo exploramos un de estos referenciales, proponiendo mapear las ramificaciones de lo pensamiento de Martin Heidegger en la concepción de Geografía de Dardel como una ciencia existencial, explorando, sobre todo, su lectura del concepto heideggeriano de la tierra buscando rescatarla e reconociéndola como suelo fundamental de todo el conocimiento.

Palabras-clave: Embate Terra-mundo; epistemología; ciencia existencial; Geografía fenomenológica; Geografía humanista 


\section{INTRODUÇÃO}

Desde o ano de 2011 a comunidade dos geógrafos brasileiros pode contar com a tradução da obra de Éric Dardel, original em francês de 1952, O Homem e a Terra: natureza da realidade geográfica (DARDEL, 2011). A tradução é um esforço por ampliar o conhecimento e estudo da obra, colocando-a a disposição da comunidade de geógrafos, sobretudo, àqueles que buscam uma abordagem fenomenológica e têm o autor como uma de suas principais referências. A obra de Dardel, no entanto, não se restringe apenas ao âmbito dessa abordagem, pois traz uma compreensão holística da relação homem-terra, além de um belo capítulo sobre a história da geografia. Assim, a obra também atinge aqueles preocupados com as questões ambientais e com a História do Pensamento Geográfico e da Epistemologia da Geografia, além de profissionais de outras áreas como arquitetura, história, filosofia (MARANDOLA JR., 2011).

Seja qual for o caso, a tradução da obra não é tardia. Por um lado porque existem ainda muitos que não a conhecem. A sua tradução e disponibilização em uma edição recente aumenta as chances de um primeiro contato com a obra. Por outro lado, mesmo aqueles que já a conhecem ou que a exploram em suas pesquisas há tempos, reconhecem que há sempre ainda o que descobrir e o que refletir sobre e a partir da construção epistemológica realizada por Dardel. Em verdade, se a noção de geograficidade é tida como cerne das discussões desenvolvidas por Dardel e no Brasil já tenha uma grande circulação entre os geógrafos (embora nem sempre seja reconhecida sua autoria), existem aspectos da obra menos discutidos ou pouco aprofundados. Como Holzer (2011) coloca, a proposição dardeliana de uma ontologia para a geografia e a extensão do significado da adoção da postura fenomenológica pelo geógrafo francês, para uma Geografia Fenomenológica, vem ganhando especial atenção nas últimas décadas com a maior difusão da Geografia Humanista e da fenomenologia no Brasil. Contudo, ainda existem possibilidades de aprofundamento, sobretudo, para aqueles que têm um interesse crescente em questões ontológicas e vêm tratando o espaço como uma dimensão da existência.

A singularidade da obra de Dardel não envolve apenas a maneira como a geografia ${ }^{2}$ pode ser entendida ou como é possível pensar a sua história para além das instituições, mas envolve também uma nova proposição de ciência. Uma ciência que compreende a relação do homem com a terra, antes de tentar explicá-la, conceituá-la ou mesmo mensurála. Esta ciência compreende o cientista, antes de qualquer coisa, como um homem que se posta diante daquilo que o cerca, sendo aquele que existe, se relaciona e vivencia antes

2 Geografia, com letra maiúscula faz referência à disciplina científica, acadêmica. Já a geografia, com letra minúscula, se refere à proposição de Dardel da geografia como uma dimensão do ser. 
de qualquer possibilidade de conhecer ou de conhecimento científico. Esta perspectiva de ciência ainda está distante de ser ponto pacífico, embora haja hoje diversas aberturas, oriundas das fissuras do próprio edifício da ciência moderna.

Nesse sentido, é crucial dedicarmo-nos ao entendimento da discussão sobre a geografia proposta por Dardel, ainda nos anos 1950 e os seus desdobramentos para uma proposição sobre a própria ciência, o que corrobora com as buscas de repensar os pressupostos e pressuposições da ciência moderna. Sem, contudo, recorrer ao risco de determinar um novo paradigma para Geografia. Não são novos paradigmas que os geógrafos humanistas propõem, pelo contrário, é a possibilidade de levar o conhecimento geográfico e o significado da própria geografia ao limite de suas potencialidades ao buscar as sendas da fenomenologia.

Éric Dardel trilhou seu caminho dialogando com a Filosofia, a Arte, a Antropologia, entre outros saberes, realizando uma construção teórica que tem nesses diálogos a sua maior força e diferencial. Dentre esses diálogos há um em particular que buscamos compreender mais detidamente partindo da identificação e compreensão da sua influência na geografia dardeliana. Uma das principais referências de O Homem e a Terra é o pensamento de Martin Heidegger. O filósofo alemão aparece na obra de maneira direta em alguns pontos, porém, sua influência é claramente identificável de forma mais ampla pela proximidade das reflexões de Dardel e a fenomenologia existencial e hermenêutica que Heidegger leva à cabo em suas ponderações sobre a ontologia. A principal obra citada diretamente é A origem da obra de arte, original de 1935/36 (HEIDEGGER, 2012a). A influência heideggeriana perpassa a obra de uma maneira geral, mas aparece de forma mais contundente na discussão sobre "Espaço Telúrico", especialmente no que se refere à discussão de Dardel sobre a terra. A própria profundidade da discussão do geógrafo advém do embasamento ontológico e fenomenológico, que busca um retorno às coisas mesmas e, assim, o fundamento ontológico da ciência geográfica.

Com o objetivo de aprofundar a compreensão dos fundamentos de O homem e a terra, e assim poder pensar sua importância e relevância para a geografia contemporânea, este artigo se propõe explorar a presença de Heidegger na obra. Este intento sistemático envolveu a leitura e releitura, vis-à-vis com a obra heideggeriana, perseguindo suas pistas e papel na construção tanto do texto quanto dos conceitos utilizados por Dardel. Isso nos permite compreender as implicações da proposta de Dardel e o que isso significa para uma ciência geográfica, especialmente pela senda da fenomenologia. Mas como este empreendimento em si merece muito mais do que este artigo comporta, nos deteremos na leitura que Dardel faz para a Geografia da concepção de terra de Heidegger e os desdobramentos dessa empreitada para uma compreensão ampliada da relação do homem com a terra. 
Mas primeiro, para potencializar a inserção da obra de Dardel no nosso contexto atual, é importante compreender como O homem e a terra esteve presente, ou melhor, porque ela esteve ausente do cenário geográfico por tanto tempo, mesmo na França onde foi publicada originalmente. Até hoje, o livro conta com uma reedição francesa (DARDEL, 1990), uma tradução italiana (DARDEL, 1986), nossa tradução para o português (DARDEL, 2011), uma tradução espanhola (DARDEL, 2013) e, mais recentemente, em um volume denominado Ecrits d'um monde entier, que reúne dois livros de Dardel, incluindo O homem e a terra, e mais um conjunto inédito denominado "Lappel du monde" (DARDEL, 2014) (Figura 01). Essa contextualização se faz necessária para compreendermos o porquê é neste período que sua obra recebe maior atenção e para que possamos compreender seu potencial para contribuir para a construção fenomenológica que se busca na geografia contemporânea. Por outro lado, ao realizar esta contextualização, procederemos a uma apresentação mais ampla da própria obra, suas características e aspectos singulares e inovadores, implicando em uma compreensão mais ampliada das consequências, para a geografia contemporânea, da adoção da fenomenologia em seu fazer e pensar.

Figura 1 - Capas das edições de O Homem e a Terra. Da esquerda para direita, de cima para baixo: Edição original francesa de 1952; edição italiana, de 1986; segunda edição francesa, de 1990; edição brasileira, de 2011; edição espanhola, de 2013; edição no conjunto Ecrits d'um monde entier, de 2014.
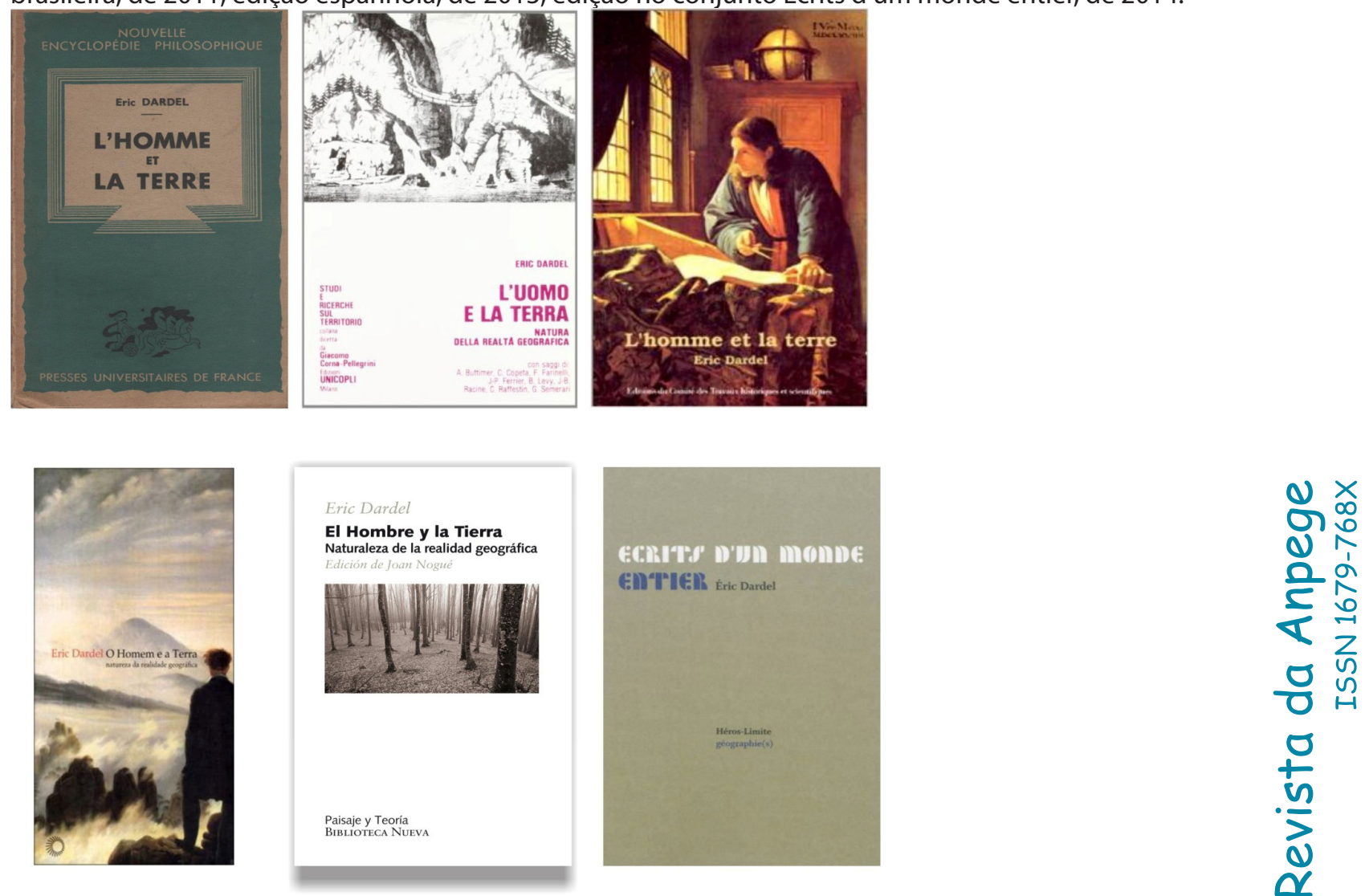

Fonte: elaborado por Priscila Marchiori Dal Gallo 


\section{O HOMEM E A TERRA: SEUS CAMINHOS PELA GEOGRAFIA}

Claude Raffestin, em um artigo de 1987, escreve sobre a repercussão de O Homem e a Terra na comunidade geográfica a partir da seguinte pergunta: Porque não lemos Dardel? Ele se questiona do porquê a obra ter se mantido tantos anos em esquecimento, sem ser mencionada ou citada por mais de uma geração de geógrafos, abandonada à "biblioteca do silêncio”. Raffestin não traz um levantamento sistemático da produção dos geógrafos para indicar a marginalidade da obra de Dardel, mas acena para possíveis respostas. Reconhecemos três indicações: (1) a linguagem poética de Dardel, (2) a conjuntura histórica e (3) renovação da ciência geográfica.

Como o próprio Raffestin admite, a linguagem que Dardel emprega em sua obra não é uma linguagem usual da ciência moderna. Mesmo nas ciências humanas os cientistas não estão acostumados com o prazer do texto; o rigor científico parece ter uma face adversa a uma escrita poética e literária. Além da forma da linguagem, para muitos que se aventuraram em sua leitura a dificuldade foi realmente entender aquilo que Dardel buscava, pois era difícil compreender o sentido de amante da terra que o geógrafo emprega em cada linha de sua escrita. Raffestin afirma que Dardel acabou sendo vítima de sua escrita poética, pois ela teria, aos olhos da comunidade geográfica, mascarado a profundidade de seu pensamento e a originalidade de suas proposições.

Há aqui uma nítida falta de sintonia entre Dardel e seus contemporâneos, tornando-o um solitário e incompreendido, deslocado de seu tempo (CHOLLIER; WADDELL, 2014). A linguagem poética, hoje apontada como possibilidade de dizer aquilo que não é dizível de outra forma (reafirmada pela tradição fenomenológica desde Heidegger, passando por Bachelard, e em sintonia também com o pós-estruturalismo), na época não encontrou eco entre uma ciência geográfica mergulhada no pragmatismo do pós-guerra e a necessidade de direcionar a geografia para contribuir com a reconstrução, recuperação econômica e o planejamento. Tal foco desloca a preocupação com as relações com a terra em um sentido existencial, como assumido por Dardel, para uma circunstância economicista das relações do homem com a terra, de modo que questões fundamentais sobre essa relação foram postergadas por gerações. Nesse cenário, diz Raffestin que Dardel era um visionário, pois aquilo que ele propunha tinha algo de inapreensível e na conjuntura do pós-Segunda Guerra Mundial a sua proposta parecia apenas tangenciar as preocupações pujantes na época. Rendidos a seu paradigma, a comunidade geográfica ignorava veementemente aquilo que aparecia em suas margens e desencontrava do contexto em vigência. Para Raffestin o espírito com que Dardel escreve a sua obra era ausente entre os geógrafos e apenas irá florescer e frutificar quando a campo da geografia se torna mais fértil às suas ideias. 
Bertrand Lévy (1996) reforça essas ideias quando afirma que Dardel realizou em sua obra uma geopoética que propunha reduzir as distâncias ontológicas entre a linguagem e as coisas ou o ser das coisas. Dardel caminha com poetas e escritores como Hölderlin, Novalis, Rilke, Samain, Shelley, Goethe, Ortega y Gasset ao longo de sua escrita, de modo que é notório que esta linguagem seja uma busca consciente por parte do geógrafo, como afirma: "a linguagem do geógrafo sem esforço transforma-se na do poeta. Linguagem direta, transparente, que 'fala' sem dificuldade à imaginação, bem melhor, sem dúvida, que o discurso 'objetivo' do erudito" (DARDEL, 2011, p. 3). Como Lévy indica, em O Homeme a Terra há uma tonalidade poética contínua, coisa que poucos geógrafos se propuseram a empregar e Dardel o faz de forma magistral com um vocabulário emocional e afetivo. Aquilo que toca a alma dos homens é o centro da geografia dardeliana. De outro modo, ele cria uma língua geográfica sensível, que acomoda o apelo da terra e é solidária à cumplicidade da relação homem e terra. Tal postura, para Lévy, é demasiadamente destoante para o positivismo, para aqueles de alma materialista. Para os últimos, o poético é uma mentira, uma ignorância derrotada pela explicação racionalista.

Com sua escrita Dardel aproxima a ciência da poética e da filosofia. Ele busca legitimar uma Geografia literária poética, que significa travar uma batalha contra a Geografia cientificista. Segundo Raffestin (1987), a geografia de Dardel tem como cerne o desvelamento de uma relação, e não a mensuração da terra. A questão é a busca pelo viver na e a terra, pois ela é uma questão incontornável a qualquer civilização, época e cultura. Nesse sentido, Raffestin afirma que a geografia dardeliana é sempre relativa ao homem, mas da maneira como ele se posta diante daquilo que o cerca, o conhecimento é dessa forma experiencial e prático. Mas prático não quer dizer metodológico, antes do geógrafo que mensura e calcula está o homem que descobre a terra. Esta postura de Dardel é uma busca de um novo entendimento da ciência.

Lévy (1996) adiciona uma quarta resposta à pergunta de Raffestin (1987). Para ele por maior que seja o seu referencial e sua erudição, existe um tom de liberdade em O Homem e a Terra que chega a ser enigmático para o autor. Dardel foi o seu próprio "patrão" quando se afastou dos percursos acadêmicos e institucionais. Ele foi um pensador livre, não um agente disciplinar, institucional e burocrático, mantendo-se à margem dos paradigmas instituídos. De modo que ele teve o desembaraço para assumir-se como um amante da arte, tendo o ímpeto de fazer uso dessa relação e da sua proximidade com a filosofia para dar uma profundidade ontológica à sua discussão. Dardel foi um daqueles pensadores à parte de um corpus acadêmico disciplinar, testando os limites do conhecimento humano e das formas de conhecer para alcançar a geografia como uma dimensão existencial do ser. Estando nas margens, Dardel torna permeáveis as fronteiras entre Geografia, Filosofia e Arte. 
De uma família de teólogos de origem suíço-germânica, Dardel teve um contexto familiar e de amizades cujo protestantismo, a filosofia e a história das religiões eram muito presentes. Chollier e Waddell (2014) destacam a importância deste contexto para o desenvolvimento de um pensamento desprendido da geografia e história vigentes à época, cujas influências estenderam-se para seu sogro, o missionário e etnólogo Maurice Leenhardt, o que contribuiu muito para o interesse de Dardel pela questão dos mitos e dos símbolos, além da biografia sobre assuntos ligados aos missionários, à existência e à história das religiões, que também acabaram objeto de seu interesse e escrita (DARDEL, 2014). Isso também foi importante para sua variedade de leituras e seu interesse pela filosofia. $\mathrm{Na}$ verdade, Chollier e Waddell (2014) mostram como o contexto intelectual de Dardel era rico, participando ativamente do círculo de intelectuais franceses protestantes que, além de tudo, eram leitores da filosofia alemã. Segundo Jacques Dardel (2014), o geógrafo ajudou a difundir o pensamento de Kiekegard, Heidegger e Jaspers na França.

Dardel foi professor e um dos fundadores do Liceu Jean-Jacques Rousseau, uma instituição caracterizada pela experimentação e inovação, sendo um dos orientadores pedagógicos (NOGUE, 2013). Segundo Jacques Dardel (2014), sua ida para este liceu, criado durante a Segunda Guerra, foi uma grande mudança em sua trajetória e lhe permitiu aproximar-se definitivamente da história e, posteriormente, da geografia. É enquanto professor do liceu que escreveu suas obras mais claramente influenciadas pela fenomenologia.

Teve uma sólida formação acadêmica, defendendo seu doutorado na Universidade de Paris, em 1939, contudo suas pesquisas foram sempre paralelas à sua atividade profissional. Suas contribuições em artigos ou em livros de geografia ou história nunca foram sistemáticas. Ele realizou contribuições à academia, especialmente na área de geografia da pesca, tema de seu doutorado (DARDEL, 1941a; 1941b; 1946a) e publicações envolvendo discussões sobre a história (DARDEL, 1946b; 1958) e os mitos (DARDEL, 2014). Porém como aponta Pinchemel (2011), nunca obteve nenhuma vantagem com elas, em termos de carreira. Dardel era um entusiasta pelos mais diversos campos de conhecimentos e meios intelectuais, dotado de uma curiosidade inata ele amplia seu leque de referências às diferentes humanidades; um verdadeiro apaixonado pelas ideias e por sua história.

Suas colaborações mais perenes foram no campo dos estudos de história das religiões, os mitos e a carreira missionária. Segundo Jacques Dardel (2014, p.31-32), colaborou para a Le Christianisme au XX scècle, de 1928 a 1958, e para a Le monde non Chrétien de 1949 a 1966 (editada por seu sogro), além de outras antes do doutoramento. 
Em função de sua relação com o meio acadêmico, sua obra O Homem e a Terra, lançada em 1952, teve uma recepção pouco entusiasmada da comunidade dos geógrafos. Não houve nenhuma movimentação da comunidade geográfica em resenhar ou mencionar a obra. Segundo Besse (2006), a publicação do livro em uma coleção de filosofia, a Nouvelle Encyclopédie Philosophique, dirigida por Émile Bréhier, não pode ser reconhecida como uma desculpa para o descaso com a obra, que permaneceu quase perdida, visto que a curiosidade dos geógrafos por uma literatura ampliada não é exclusividade das novas gerações. Para Besse, o problema está nos princípios estabelecidos pelos geógrafos, sobretudo, da Nova Geografia, sobre aquilo que deveria ser compreendido como a Geografia, isto é, uma análise espacial. Tal concepção estava longe de estar aberta à discussão de modo que as propostas de Dardel eram inassimiláveis pela comunidade geográfica. "Se Dardel está à margem é porque ele visa um nível de radicalidade na definição da geografia, que transborda singularmente as análises propostas, na soleira dos anos cinquenta, nos meios geográficos de ofício" (BESSE, 2006, p. 84 - destaques do autor).

Na França, o silêncio quase absoluto sobre sua obra só foi rompido em 1973, 21 anos após a edição de seu livro, pela sua inclusão no livro Panorama des sciences humaines, de Denis Hollier. Segundo Chollier e Waddell (2014, p.12), Hollier reconheceu o caráter inovador da escrita de Dardel como uma crítica à geografia feita à época.

Apesar desta menção, Dardel só será de fato redescoberto e discutido por geógrafos anglo-saxões que engendram o movimento de revisão epistemológica da Geografia, na virada dos anos 1960 para 1970, em especial, aqueles que participam do movimento da Geografia Humanista, como Edward Relph, Anne Buttimer e Yi-Fu Tuan (HOLZER, 1993; 2010a; DARDEL, J., 2014). Holzer (2011) aponta que será Relph o principal responsável por resgatar a obra de Dardel em sua tese The Phenomenon of Place, defendida em 1973 (publicada três anos depois como o clássico Place and placelessness - RELPH, 1976), na qual chama atenção para a fenomenologia como um método para a Geografia.

Holzer (2010a) afirma também a importância da Universidade de Toronto, no bilíngue Canadá, onde alguns destes geógrafos estavam (ou por ali circulavam) e onde foram veiculadas críticas à geografia da percepção de base comportamentalista. Neste contexto, Holzer afirma que Dardel respondia muito bem às buscas daqueles geógrafos, especialmente no que tange o conceito de lugar, que opera, segundo o autor, como um catalizador destes interesses e coloca a obra de Dardel no centro deste movimento inicial da geografia humanista norte-americana.

A partir desses autores e a disseminação de seus trabalhos entre diversas comunidades geográficas do mundo, a fenomenologia e Dardel passam a ganhar atenção. Na Europa, 
França e Itália, Dardel será redescoberto nas décadas de 1980 e 1990. No mundo francófono, Holzer (2010a) aponta André-Lous Sanguin, da Universidade de Quebéc, como tendo resgatado o livro de Dardel e o equiparado ao seminal texto de John Wright (1947; 2014) para o surgimento das abordagens humanistas (SANGUIN, 1981). Na Itália, Clara Copeta traduz e publica a obra em 1986, com um conjunto de textos de autores italianos e de outros países repercutindo o texto dardeliano. Já na França é reeditado em 1990, motivado pelo interesse oriundo da tradução italiana, com os comentários de Jean-Marc Besse e Phillipie Pinchemel (DARDEL, 1986; 1990).

Nesse sentido aqueles que buscavam, como Dardel, repensar a Geografia adotaram a obra do autor como uma importante referência. É importante ressaltar, contudo, que Dardel não representa um novo paradigma da Geografia. Pelo contrário, a obra se recusa a ser uma nova constituição conceitual pragmática e paradigmática. Como Lévy (1996) afirma, O Homem e a Terra pode ser entendido como uma profunda reflexão que transforma o sonho dardeliano em linguagem de criação, indicando que seria um erro do intérprete, geógrafo e leitor, aprisionar seu espírito em categorias dogmáticas.

No Brasil, a obra, embora fosse citada e utilizada desde o final dos anos 1980, acompanhando o desenvolvimento da própria Geografia Humanista (MARANDOLA JR.; GRATÃO, 2003), teve sua tradução somente em 2011, no contexto de sistematização e crescimento dos estudos humanistas, especialmente pela senda fenomenológica. Seu tradutor, Werther Holzer, é um ativo difusor e estudioso da fenomenologia e da Geografia Humanista, fundando e coordenando o Grupo de Pesquisa Geografia Humanista Cultural (GHUM), que tem promovido, paralelo a outras iniciativas, estes estudos no Brasil na última década.

Assim, é notório que o contexto de recepção da obra e sua possibilidade de frutificar, no Brasil, também é muito mais favorável hoje, com a ampliação e aprofundamento das matrizes fenomenológicas (MARANDOLA JR., 2013), do que seria em qualquer outra década anterior. Vivemos um período muito importante na geografia brasileira contemporânea, com possibilidades de diálogos mais intensos com a Filosofia e a Arte (com as humanidades em geral), com um novo ímpeto em direção às relações possíveis entre Geografia e Fenomenologia, tanto por parte de geógrafos quanto de filósofos (MARANDOLA JR., 2012).

Um contexto semelhante pode ser compreendido na Espanha, cuja geografia durante todo o período do pós-guerra foi predominantemente aplicada e, embora Dardel fosse utilizado e citado por alguns autores, sua tradução só encontrou eco recentemente, mas, contraditoriamente, em um ambiente provavelmente mais receptivo às suas ideias (NOGUE, 2013). 
Não por acaso, Dardel cai como uma luva neste contexto, permitindo o aprofundamento destas relações e novas possibilidades para a Geografia se pensar como ontologia e como conhecimento experiencial ou, como se refere Dardel, como "vivida em ato".

Uma nova edição francesa veio à luz em 2014, mas em um contexto mais amplo. Junto com o livro de 1946 sobre história (DARDEL, 1946b), nunca reeditado, e mais um manuscrito que nunca fora publicado, o volume Ecrits d'un monde entier, tem como editores e mediadores dois geógrafos envolvidos com estudos etno-eográficos e geopoéticos. Alexandre Chollier, que colabora com o Département de Géographie et Environnement da Université de Genève, Suiça, e Éric Waddell, da Université Laval, no Quebec. O contexto em que esta nova edição surge denota um novo contexto de interesse mais amplo pelo legado e pelo pensamento de Dardel, o qual merece reflexão e compreensão ainda por ser delineado no futuro.

\section{HOMEM E A TERRA: GEOGRAFIA DARDELIANA}

Com o resgate da obra de Dardel a Geografia vislumbra possibilidades de levar a cabo um projeto científico geográfico, embalado não pelo positivismo e sim pela procura de uma ontologia. Dardel é um dos poucos geógrafos que se dedicou a um projeto epistemológico e ontológico para a geografia, encarando a fenomenologia não apenas como uma possível metodologia, mas sim como uma possibilidade inteiramente nova de enxergar a ciência geográfica: uma nova ontologia da geografia. Portanto, a geografia de cunho fenomenológico que Dardel realiza não se reduz a uma ampliação ou complexificação do entendimento das relações do homem com a Terra, mas de realizá-la desde seu sentido visceral, que significa, assumir a geografia não como um conteúdo ou um conhecimento, mas uma dimensão do ser do homem.

Besse (2006) afirma que todo esforço de Dardel em conduzir um encadeamento entre Geografia e Fenomenologia caminha para uma radicalização da pergunta sobre a identidade não só da Geografia, como também, do próprio geógrafo. A pergunta pela Geografia e a pergunta pelo ser geógrafo reside em uma pergunta ainda mais inquietante "que é habitar geograficamente a Terra?". Desse modo, Dardel realiza, ao mesmo tempo, uma reflexão epistemológica e ontológica da geografia e busca orientá-la pela compreensão do sentido da geografia para o ser humano, ou o sentido do ser geográfico. Neste sentido, Dardel esbarra nas limitações da ciência ou da cientificidade da ciência moderna que governou a Geografia, na medida em que esse sentido não pode ser objetivado.

A resposta que Dardel constrói para sua própria pergunta "que é a geografia?" vem na contramão do próprio fazer científico, visto que a ciência moderna coloca o 
conhecimento em termos de uma relação segmentada entre sujeito e objeto. Para Dardel, tal encaminhamento do pensamento é contraditório com a realidade geográfica. Seu entendimento é guiado por um posicionamento fenomenológico-existencial que acena para uma impossibilidade de separação; a origem da realidade geográfica já reside na própria interdependência entre homem e terra. Não há, portanto, homem e terra e depois a (re) união deles; a realidade geográfica está fundada já na experiência humana de ser-com. A existência humana é compreendida como o ato em que o homem se coloca ao alcance das coisas, ele se projeta na e em relação "Ao mesmo tempo em que procura tornar as coisas próximas, o homem necessita de, por sua vez, se dirigir, para se reconhecer no mundo circundante, para se encontrar" (DARDEL, 2011, p. 11 - destaque do autor). Para Dardel, a experiência é extensão em sua essência ou um movimento de procurar pela proximidade das coisas, não em termos quantificáveis de mensuração de distâncias, mas a procura de abertura de horizontes de compreensão e relacionalidade.

Aqui já fica, previamente nítida, a influência da ontologia fundamental de Heidegger (2012b) e sua compreensão do ser-no-mundo e da intencionalidade como maneira de dirigir-se ao mundo (Umwelt, ou mundo circundante).

O encadeamento entre geografia e fenomenologia de Dardel implica em realizar uma fenomenologia que compreenda a realidade geográfica ou o espaço geográfico pelas vias da experiência, mas não qualquer experiência, e sim aquela que vigora no âmbito préreflexivo, que é originária: uma experiência imediata dos fenômenos. Reconhecer esse caminho é, para Dardel realizar a geografia verdadeiramente, no sentido de colocar o ser na verdade, na própria possibilidade do desvelamento do ser naquilo que ele é e como é: geográfico. A geografia traz o homem pra o seu ser-para-a-verdade. A geografia chama o homem a cumprir seu destino de vigília, de pastorear o ser, aquele que tem por vocação (inesquecível) ouvir aos apelos da terra.

Para Besse (2011), o maior desafio da Geografia dardeliana é o reconhecimento da necessidade de se retornar a este mundo anterior à ciência, do qual ela se afastou ao longo dos anos. O desafio é restituir a dependência das ciências ao mundo da vida, desafio já proposto por Edmund Husserl quando reconhece em sua obra A crise das ciências europeias e a fenomenologia transcendental (HUSSERL, 2012) o cerne da crise das ciências modernas. Assim, Dardel se coloca a tarefa de reconstituir a consciência científica do geógrafo desde sua fundamentação, que é nada menos que a sua própria presença na terra. O geógrafo deve (re)conhecer e (re)descobrir a sua existência terrestre (BESSE, 2006). A compreensão da Geografia precisa se desvencilhar da ideia de objeto, da realidade ou espaço geográfico como objeto diante do sujeito ou agente. Ela é elementar, um evento original da existência. 
Dardel busca reconduzir o homem a compreender a terra com um interesse existencial, que corresponde entender o saber geográfico como a sua própria morada na terra (BESSE, 2011).

Em suma, a geografia desvela a própria possibilidade de ser-no-mundo. Ela desvela as possibilidades desse ser enquanto geograficidades: experimentações diversas que possuem o mesmo solo pátrio: a terra. De modo que o geógrafo não busca objetivar os fenômenos terrestres e circunscrevê-los por meios representacionais, mas entendê-los desde o seu instante emergente e assim reconhecer a sua verdade. Dardel pergunta-se pela constituição epistemológica do conhecimento geográfico no contexto de um questionamento ontológico sobre a essência da geografia. Seria a geografia uma ciência essencial? Besse (2006, p.85) responde: “Todo objetivo de Dardel será mostrar que a geografia está envolvida em sua própria essência, por esta indagação ontológica concernente ao homem, e que é ali que ela encontra finalmente seu sentido mais verdadeiro". Esta seria a natureza da realidade geográfica (subtítulo do livro), região ontológica de preocupação da Geografia.

Nesse sentido, quando Dardel afirma ser a Geografia uma disciplina compreensiva, mais do que explicativa, e assume essa compreensão como advento do conhecimento humano ele propõe (1) a compreensão do como da experiência geográfica e; (2) o compreender-se como ser-no-mundo a partir dessa última. Isso significa, segundo Besse (2011), ser capaz de traduzir a emoção bruta que a surpresa do encontro com o terrestre faz nascer em uma linguagem essencial e sensível que traga essa emoção à luz. Em outras palavras a Geografia deve ser um trazer à tona o fundamento ontológico da experiência geográfica pelas vias da compreensão.

Essa tarefa é nada mais, nada menos que elucidar a presença do terrestre. A Geografia deve ser uma linguagem capaz de elucidar, desvelar algo que insistentemente parece escapar da consciência. A Geografia deve trazer à compreensão a cumplicidade vivida entre homem e terra, ou a compreensão da intimidade do e com o terrestre. Para tanto é necessário que aquilo que denominamos de terra seja revista, para que a compreensão não se limite a uma morfologia, um embasamento material. Dardel visita a concepção heideggeriana de terra para orientar seu entendimento. Heidegger irá pensar a terra como aquele fundo do qual o mundo se abre, emerge:

O mundo funda-se na terra e a terra irrompe pelo mundo. Só que a relação entre mundo e terra não se reduz e maneira alguma à unidade vazia dos opostos que não têm nada que ver [um com o outro]. O mundo aspira, no seu assentar sobre a terra, a fazê-la sobressair. (HEIDEGGER, 2012a, p. 47).

Por um lado a terra será o solo pátrio para pensar uma geografia original, uma ciência de cunho existencial, pois é a terra o fundamento possível de todo o conhecimento e do 
próprio mundo. Neste sentido, o mundo é um horizonte de abertura e de compreensão que se realiza pela própria condição de ser-no-mundo do homem. Por outro lado, a terra persiste como um fundo misterioso à apreensão humana, mas que se torna invariavelmente a morada do homem.

Em ambos os questionamentos Dardel tem um amplo embasamento no pensamento heideggeriano. A ontologia heideggeriana caminha, na fase tardia de seu pensamento, para uma discussão sobre o habitar e o poético, na qual as reflexões sobre o ser transformamse em um questionamento em como o ser pode ser (MALPAS, 2008; SARAMAGO, 2008). O filósofo elabora sua resposta em sua discussão sobre o mundo e sua própria estrutura (que está sempre em correspondência com a concepção da terra).

\title{
O PENSAMENTO HEIDEGGERIANO EM DARDEL: A CIÊNCIA E 0 TELÚRICO
}

A discussão sobre a geografia dardeliana realizada no item anterior já nos acena para as implicações da adoção da fenomenologia pela Geografia na reflexão de sua própria identidade e de sua própria concepção de ciência. Quando se estabelecem as singularidades dessa última sob orientações fenomenológicas, realizando uma Geografia fenomenológica, propomos fazer uma discussão ou uma reflexão sobre a ciência geográfica nos termos em que Heidegger colocou durante seu curso de verão de 1928 a 1929 na Universidade de Freiburg, intutulado Einleitung in die Philosophie $e^{3}$ que seria posteriormente publicado no segundo volume da coleção Heidegger Gesamtausgabe - Lecture Courses, 1919-1944. Tal trabalho faz uma longa discussão envolvendo a pergunta pela essência da ciência e procura fazer uma proposição ontológica e fenomenológica para sua compreensão, trazendo para a discussão a noção de verdade como desvelamento e a compreensão do ser-aí (Dasein) como caráter pré-científico do conhecimento para então (re)colocar as bases da ciência e tratá-la enquanto um projeto ontológico.

Se quisermos recorrer ao próprio texto de O Homem e a Terra, podemos nós valer simplesmente de seus primeiros parágrafos para pensar nas possíveis influências que a discussão sobre ciência, dos cursos de Heidegger, exerceu sobre ele. Logo de início, Dardel já procura dizer aquilo que ele está propondo como entendimento da geografia:

\begin{abstract}
Mas antes do geógrafo e de sua preocupação com uma ciência exata, a história mostra uma geografia em ato, uma vontade intrépida de correr o mundo, de franquear os mares, de explorar os continentes. Conhecer o desconhecido, atingir o inacessível, a inquietude geográfica precede e sustenta a ciência. Amor ao solo natal ou busca por novos ambientes, uma relação concreta liga o homem à Terra, uma geograficidade (géographicité) do homem como modo de sua existência e de seu destino. (DARDEL, 2011, p. 2 - destaques do autor).
\end{abstract}

\footnotetext{
3 Essa publicação ganha uma tradução no Brasil em 2008 por Marco Antonio Cassanova, na editora Martins Fontes, sendo intitulado: Introdução à Filosofia e uma reedição em 2009.
} 
É dessa primeira surpresa do homem frente à Terra e à intenção inicial da reflexão geográfica sobre essa "descoberta" que se trata aqui, questionando a geografia da perspectiva do próprio geógrafo ou, mais simplesmente, do homem interessado no mundo circundante. (DARDEL, 2011, p. 2 - destaques nossos).

É possível pensar nesses primeiros parágrafos como uma tradução, com maestria, da proposta de Heidegger sobre a ciência em termos geográficos. Ou seja, Dardel conseguiu compreender plenamente o que essa ciência existencial heideggeriana seria quando pensamos como geógrafos. Mas aqui existe o esforço não só de pensar em termos da Geografia e os caminhos de seu saber constituído, isto é, a disposição por realizar uma reflexão ou reexame dos fundamentos da ciência geográfica buscando o tratamento epistemológico de seu objeto, questionando 'qual objeto é esse?' 'qual a sua fundamentação?'. Destrinchar essas questões é de alguma maneira buscar pela fundamentação da ciência desvelando a relação entre o sujeito e o objeto. Essa relação coloca as condições de experiência do sujeito no mundo e a possibilidade de conhecer. Dardel busca pensar a geografia como o fundamento, como uma dimensão da existência, não apenas como uma disciplina. O geógrafo habita o mundo, está na terra e procura entender-lhes as estruturas e intercâmbios.

Falamos da proposição de ciência de Heidegger, contudo ainda não desenvolvemos tal proposição. Será essa a nossa próxima tarefa, de modo a deixar mais claro aquilo que estamos querendo defender: a leitura de Dardel das proposições heideggerianas guiaram, em alguma medida, o seu entendimento sobre a Geografia.

\section{A CIÊNCIA EXISTENCIAL DE HEIDEGGER E A GEOGRAFIA}

Segundo Silva (2013), para Heidegger as discussões sobre a metafísica como ciência ou o caráter científico da problemática metafísica teria mantido oculta pela preponderância da concepção ôntica da ciência moderna, sobretudo das naturais, o ser. Na concepção heideggeriana, o mundo é compreendido como abertura e assim como possibilidade do conhecimento, de modo que a presença e o estar-no-mundo se coloca como precedência necessária para uma forma de conhecimento especifico que é o científico. O científico, desse modo, está sempre vinculado a um estado pré-científico de ser-e-estar-no-mundo que se realiza pelo acesso ao ser do ente. Há uma relação essencial entre o ser e o ente em que o primeiro é condição de possibilidade de acesso ao segundo: o ente só pode ser acessado se manifesto como o que é. Ou seja, o conhecimento ôntico, que acessa o ente, tem uma base ontológica ou é antes de tudo um conhecimento ontológico. Como o próprio filósofo coloca: 
Não chegamos primeiramente ao giz [que é o giz] por meio do caminho do enunciado e do contexto relacional ao qual esse anunciado está supostamente atrelado, mas, inversamente, somente na medida em que já estamos junto ao giz, na medida em que já nos mantemos junto a ele, ele pode ser um objeto possível de enunciado. (HEIDEGGER, 2009a, p. 69).

Para Heidegger (2009a), é imprescindível pensar a ciência não como um resultado, uma obra ou um simples produto; o filósofo se questiona sobre a sua essência, buscando compreender essa essência no processo de atuação da própria ciência. Para ele essa essência reside na verdade, ou no desvelamento. Ciência significaria ser na verdade, mas ser na verdade em virtude do desvelamento dos entes aos quais o ser-no-mundo se mantém junto a. Essa é a fundação do conhecimento: a verdade, como desvelamento. O Dasein ou ser-aí, por ser um ser-aí pré-científico, não é um ser-aí que tem sua verdade desde o conhecimento científico, pelo contrário, o ser-aí dispõe do conhecimento de forma originária, ele as descobre em seu próprio ato de existir. Esse conhecimento pré-científico (ontológicoexistencial) se torna em conhecimento científico (enunciado) quando o ser-aí se dispõe a própria postura científica em seu sentido heideggeriano: "o comportamento especificamente científico caracteriza-se por constituir-se a partir de uma escolha do próprio dasein, que atribui livremente a si mesmo a tarefa de descoberta dos entes [...] no intuito de revelar o que e como são estes entes" (SILVA, 2013, p. 62).

Heidegger (2009a) estabelece o comportamento científico como um movimento de objetificação, isto é, tornar algo em um objeto temático. Nesse movimento a ciência realiza uma projeção da constituição ontológica do domínio dos entes adotados como campo de investigação. A ciência circunscreve aquilo que Heidegger (2009a) chama de um projeto de constituição ontológica do ente, no qual ela elege uma região ontológica para se deter. Esse projeto é um projeto fundador; é a possibilidade interna do próprio conhecimento, ou melhor, de sua produção. A essência da ciência reside no achar-se-aí-defronte do ente manifesto nele mesmo, isto é, a verdade ôntico-ontológica.

Essa concepção de ciência não busca tratar de uma teoria geral sobre o ser como resposta a indagações de cunho científico, mas sim de emplacar uma investigação demonstrativa, ou melhor, "mostrativa" que projete aquilo que permanece não visto ou naquilo que se mantém assentado à abertura do mundo (BARRETO, 2012). Para tanto é necessário uma adequação metodológica que possa dar conta do projeto fundador da ciência e demarcador de sua região ontológica, uma metodologia que dê aos conceitos fundamentais da ciência o contexto de sua constituição. Essa adequação culmina na formulação da fenomenologia.

A fenomenologia é um caminho que busca revelar o ser, isto é, dar um passo atrás ao comportamento objetificante da ciência e elucidar essa fundação ontológica. No sentido 
que Heidegger a opera, fenomenologia trata-se de um caminho que permite a revelação do ser por meio do pensamento e toma a facticidade como elemento regente da ciência: "O incontornável [a facticidade dos fenômenos] rege e reina na essência de toda ciência (HEIDEGGER, 2012c, p. 55). Heidegger dedicou grande parte de seu projeto intelectual à compreensão clara da forma de pensar fenomenológica, mantendo um fascínio e uma inquietude persistente pela pergunta "de onde vem e como se determina, segundo o princípio da fenomenologia, aquilo que deve ser experimentado como a 'coisa ela mesma'?". A fenomenologia de Heidegger é a própria possibilidade do pensar e corresponde de formas diferentes em momentos diferentes a exigência daquilo que há que se pensar: o ser (HEIDEGGER, 2009b).

A fenomenologia seria a proposta de uma nova concepção, a partir de um propor-se a pensar fenomenologicamente, de um método descritivo, ou para mais além de uma ciência fundamental, como aparece em Husserl, originando uma arqueologia fenomenológica (ALES BELO, 2000; MARANDOLA JR., 2005). A fenomenologia intenta ser uma ciência das ciências buscando explicitar os fundamentos ontológicos de toda a ciência, de modo que ela possa desvelar a ontologia do mundo vivido que subjaz às ciências. A descrição fenomenológica é um procedimento de descobrir as estruturas essenciais subjacentes que fornecem o arcabouço para a criação do mundo, a fenomenologia "seeks to ground the relationship between the scientific and pre-scientific, the theoretical and the everyday, ontologically" (PICKLES, 1985, p. 141).

A postura fenomenológica está comprometida com a constituição ontológica das formulações teóricas, essa constituição se dá essencialmente pelo “ser junto a", pois é próprio do ser-aí colocar-se manifesto concomitantemente com o ser o ente de que está diante. Esse fundamento ontológico que a fenomenologia propõe buscar, quando pensamos na obra de Dardel, se manifesta na experiência geográfica como ele mesmo coloca:

[...] a experiência geográfica, tão profunda e tão simples, convida o homem a dar à realidade geográfica um tipo de animação e de fisionomia e que ele revê sua experiência humana [...] Entre o Homem e a Terra permanece e continua uma espécie de cumplicidade no ser (DARDEL, 2011, p.6).

A experiência geográfica que se remete invariavelmente à experiência humana remete a essa noção de cumplicidade, a qual traz consigo uma questão mais profunda referente à própria ideia de fundamento ou de origem. A compreensão dessa experiência geograficamente desde a cumplicidade do homem com a terra significa caminhar para uma compreensão da terra como fundamento, talvez mais do que isso, se trate de um esforço de elucidar a presença da terra como esse fundamento, já que “A realidade geográfica exige 
uma adesão total do sujeito, através de sua vida afetiva, de seu corpo, de seus hábitos, que ele chega a esquecê-los, como pode esquecer sua própria vida orgânica. Ela está, contudo, oculta pronta a se revelar" (DARDEL, 2011, p. 34) e "Antes de qualquer escolha existe esse 'lugar' que não pudemos escolher, onde ocorre a 'fundação' de nossa existência terrestre e de nossa condição humana" (DARDEL, 2011, p.41).

Dardel compreende a terra como a base e o fundamento de todo e qualquer despertar de consciência. Ela é para o humano aquilo que suporta sua humanidade, seu ser; aquilo do qual provem todas as suas obras, seu construir e seu erigir, isto é, a terra é toda a possibilidade de habitar, edificar, cultivar do homem, porque ela é a condição mais concreta e mais imprescindível de sua existência. A compreensão do encontro com a Terra como esse fundamento ontológico é para Dardel nada banal, embora cotidiano. Quando compreendido em sua real significância, esse encontro é uma evasão para uma nova dimensão do ser: "A Terra é, por excelência, para o homem, como destino, a circunstância (circumstare), aquilo que se ergue à sua volta e mantém sua presença como engajamento no Ser" (DARDEL, 2011, p. 43 - destaque do autor).

Quando lança a necessidade da compreensão da Terra para além de sua materialidade, para estabelecer as relações entre a existência e a realidade geográfica, Dardel elege a concepção heideggeriana de terra para encaminhar sua discussão, a partir de A origem da obra de arte (HEIDEGGER, 2012a), que foi escrito em 1935/36 e publicada originalmente no quinto volume da coleção Heidegger Gesamtausgabe, em 1950, por Vittorio Klostermann. É nesse texto em que Dardel encontra a essência da Terra: fundo escuro de onde todos os seres saem para a luz. A grande obra do homem é então trazer o ser para a luz, sem nunca conseguir se esquivar de sua obscuridade original. O homem em sua obra testemunha o embate original entre a terra e o mundo:

É essa luta incessante entre a luz e a escuridão, entre o Homem e a Terra, que confere a toda construção humana o que ela tem de concreta e real, e toda descoberta da Terra, toda "geografia", ao mesmo tempo que é, de alguma maneira, concessão a terra, abandona a fonte que nos faz existir, manifesta nossa historicidade fundamental (DARDEL, 2011, p. 43).

Para compreender a profundidade dessa discussão que surge com essa ideia de embate, convém explorar o tratamento que Heidegger deu a questão. Partimos para elucidar o que o filósofo construiu como a noção de terra e o embate estabelecido entre terra e mundo.

\section{O CONCEITO DE TERRA NO PENSAMENTO HEIDEGGERIANO E A SUA LEITURA DARDELIANA}

O conceito de terra no pensamento heideggeriano ganha densidade com as discussões sobre a verdade, ou a essência da verdade realizada em $A$ origem da obra de 
arte (HEIDEGGER, 2012a), pois a terra é discutida para além de seu caráter mineralógico, concreto ou material, tendo o seu significado ampliado. A terra é aquilo que dá resguardo, dá fundamento ao habitar do homem no mundo. E se não há como esquecer essa concretude terrestre, há como compreendê-la como uma condição existencial, sem reduzi-la à ideia de recurso, mas envolvendo tudo aquilo que esse existencial significa. A terra é, portanto, aquilo que está aí gratuitamente e sem nenhum sentido pré-definido, sem uma destinação, mas é aquilo que dá sustentação a tudo que existe:

Todas as coisas da terra, e ela mesma no seu todo, se derramam numa unissonância recíproca. Mas este derramar não é um dissipar. Corre aqui a corrente, que assenta sobre si, da delimitação que limita tudo aquilo que está presente no seu estar-presente. Desta forma, em cada uma das coisas que se fecham [ocultam] há o mesmo não-conhecer-se. A terra é aquilo, que por essência, se fecha. (HEIDEGGER, 2012a, p. 45).

Logo no início do item "Espaço Telúrico", do Capítulo I - "O Espaço Geográfico” de O Homem e a Terra, essa perspectiva sobre a terra é colocada de forma clara e explicita. Dardel afirma categoricamente que o espaço geográfico não é apenas superfície, ou seja, não é apenas matéria e que a profundidade e a espessura do geográfico se referem diretamente à experiência, mas não qualquer experiência e sim a uma experiência primitiva, referindose à ideia de fundação: "Há uma experiência concreta e imediata onde experimentamos a intimidade material da "crosta terrestre", um enraizamento, uma espécie de fundação da realidade geográfica" (DARDEL, 2011, p. 15). Em outra passagem, ele complementa: "Ocorre, assim, que o que é, num sentido completamente concreto, experimenta-se como o essencial ou o fundamental de toda a geografia, como potência telúrica” (DARDEL, 2011, p. 16).

Essa potência telúrica reside no próprio caráter da terra como aquilo que não sendo impelida para nada, que é sem esforço e incansável de onde tudo emerge e se resguarda; onde o homem encontra a seu habitar permanente (HEIDEGGER, 2012a). A experiência primitiva se dá pela própria abertura da terra ao homem. Como Dardel (2011) coloca, ela se abre em um chamado ou um apelo dos encantos dos vales, planícies, escarpas e montanhas. O homem responde a esse apelo por vocação, pois este é seu destino devido à sua inquietude e curiosidade inatas, atraído por esses encantos inescapáveis que convocam o homem a descobri-los ou colocá-los em descoberto às entranhas do solo’.

Em uma citação direta de A origem da obra de arte feita por Dardel (2011) em a "Existência e Realidade Geográfica", no final do primeiro capítulo, a concepção de terra se apresenta no sentido de physis. O caráter imperturbado da obra arquitetônica e artística que repouso sobre o solo rochoso da Grécia, encontra na obscuridade da rocha um suporte rude que resiste as tempestades impiedosas e revela o fulgor da rocha e a deixa aparecer a partir do repouso não sendo impelida para nada. Essa emergência, esse irromper no seu 
todo, Heidegger afirma que os gregos desde sempre chamaram de physis; ele decide chamar de terra (HEIDEGGER, 2012a, p. 39).

Para Biemel (1996), existe uma profundidade nessa compreensão sobre a terra em Heidegger, pois a concepção de physis significa a própria possibilidade da auto-emergência ou do mostrar-se de todas as coisas. A physis em Heidegger não se remete à ideia de natural advinda dos romanos, que é prevalente no nosso entendimento sobre natureza, mas sim o natural como aquilo que não necessita de ser produzido, porque já está e já é presente, isto é, um ser presente por si mesmo, aquilo que emerge por si mesmo e assim se demora.

Talvez essa seja uma indicação chave para a compreensão daquilo que Heidegger buscou elaborar como terra, ou seja, a noção de uma reserva secreta, algo que os gregos chamariam de lèthè, o esquecido. Com isso a ideia de potência telúrica de Dardel ganha novas proporções, podendo ser concebida como a própria ideia de fundamento. Quando Dardel coloca a terra como a condição existencial do homem, podemos pensá-la como a própria possibilidade do existir do homem e da realidade geográfica: "Existir é para nós partir de lá, do que é mais profundo [...], do que é 'fundamental”' (DARDEL, 2011, p. 41).

A terra para Heidegger (2012a) conserva o seu sentido literal, do material e dos materiais, contudo, o filósofo tem o esforço de perscrutar o seu sentido ontológico, o que significa perguntar pela essência da terra. Em sua discussão sobre a obra de arte, o filósofo irá colocar a pergunta: O que é a terra, para que chegue ao não-encoberto precisamente desse modo? (como uma reserva secreta, que emerge e fecha-se em si mesma). Ele desenvolve dizendo que é possível buscar analisar uma rocha de diferentes maneiras, seja pelo seu peso, seja pulverizando-a, contudo a rocha recusa qualquer intromissão em si, qualquer tentativa de expô-la redunda em uma imediata retração ao seu caráter próprio de ocultar-se no maciço. De modo que, a terra se manifesta quando permanece misteriosa, só aparecendo abertamente como terra, como fundo. Essa pergunta caminha para a compreensão da noção de fundamento, isto é, o porquê algo tem a possibilidade de ser como é e enquanto é. A terra só aparece como resguardo daquilo que é, mas sendo aquilo insuscetível ao descerramento. (HEIDEGGER, 2012a).

Em termos da relação homem e a terra, a terra é compreendida como base original da realização, sendo precisamente aquilo que permite a geograficidade dardeliana. Todas as relações de habitar, construir, cultivar e circular têm como fundamento a terra, não só como suporte material e sítio, mas como o principal elo de unidade, operando como a terra pátria genuína: "Para aqueles a quem é dado o poder de exprimir esses laços profundos, a Terra é o 'país', essa experiência primordial e inesquecível” (DARDEL, 2011, p. 94). A 
terra acolhe as coisas em sua essência, de forma originária, pois a terra nela mesma é parte constituinte dessa essência. De outro modo, podemos pensar que a essência da terra é ser a origem; é ser a procedência da essência das coisas: "Antes de toda escolha, existe esse 'lugar' [terra] que não pudemos escolher, onde ocorre a 'fundação' de nossa existência terrestre e de nossa condição humana" (DARDEL, 2011, p. 41).

A compreensão dessa essência da terra se dá no pensamento heideggeriano na vinculação entre terra e mundo, ou melhor, no embate terra-mundo. O filósofo pensa o mundo como uma fissura, uma abertura na terra. Mundo põe as vistas a terra em um embate entre a revelação e a ocultação. O mundo o é enquanto desocultação e descoberta da própria terra que por sua natureza mantém-se como uma sombra onipresente (na qualidade de fundo). Mundo e terra são, assim, essencialmente distintos, mas são impelidos um ao outro, nunca existindo em separado. A terra para aparecer como terra deve ser compreendida na abertura do mundo; o mundo desvela a terra como terra quando emerge dela. A terra está no próprio existir do mundo, pois se o mundo há de se fundar ele deve fazê-lo desde a terra, “como amplitude vigente e via de todo o destino essencial" (HEIDEGGER, 2012a, p. 48).

A terra preserva algo sempre de inexplorado, de desconhecido que não pode ser esgotada pelo e no entendimento do mundo, embora a terra tenha que ser compreendida como mundo, ela se mantém inabalável, imperturbável e inexaurível. Dardel (2011) faz uma leitura muito clara do embate terra-mundo como uma maneira de resguardar o caráter propriamente terrestre da terra: a terra como circunstância inexorável do homem.

Dardel coloca esse embate em termos do despertar de uma consciência geográfica, quando as feições e fisionomias terrestres se apresentam ao homem, o qual adota uma atitude diante delas correlacionando-se com elas cotidianamente por uma "inquietude central, a uma luta efetiva contra o 'fundo escuro' da natureza circundante" (DARDEL, 2011 , p. 47). Ele atribui à terra a possibilidade do despertar da consciência de mundo: "É desse 'lugar' [terra], base de nossa existência, que, despertando, ganhamos consciência do mundo" (DARDEL, 2011, p. 40). Isso significa que a terra não é um objeto que se dá à nossa percepção. Quando buscamos tratar a terra de forma objetiva o seu caráter terrestre se dissipa, a geografia é, assim, mais vivida do que exprimida e enunciada. É preciso que ela seja desvelada ou que ela venha à luz pelo desejo do homem de colocá-la em descoberto, o que acontece de forma genuína (direta e pura) ao criar sua própria geografia, que pode ser vista em termos de um embate incessante de retirar a terra de sua obscuridade, sem nunca subtraí-la dela mesma. Esse embate é algo de elementar na experiência geográfica. 
A geografia vivida em ato (a geograficidade) é a própria abertura de um horizonte compreensivo: o mundo. É isso que Dardel quer dizer quando afirma que a terra não se dá como dado bruto, sendo algo "interpretado pelo homem", um esclarecimento a partir da qual a consciência geográfica se desenvolve e dá origem a uma estrutura ou um horizonte de mundo. Essa estrutura é algo que carece de cuidado e vigília todo o tempo, tendo traços de fragilidade, na medida em que ela não é uma propriedade dada, mas é uma ação, uma intenção e um movimento. Ela é a geografia em ato onde o embate terra-mundo é travado interruptamente. Vencer a clausura da terra é um ato existencial.

Esse embate implica lidar com uma grandeza superabundante a qual o ignora. Em vista disso, há um combate incessante que visa vencer a clausura da terra, mantendo o mundo em vigência. No momento do abandono desse esforço há o esvaziamento do mundo e a prevalência do fundo escuro, a obra humana quando abandonada retorna a seu estado oculto. Neste momento, o homem "exprime sua decepção quando ela [terra] não lhe apresenta mais que a pura objetividade de um existente bruto" (DARDEL, 2011, p. 44). Desse modo, para Dardel, o espaço geográfico é instituído; como o ato que se dá no âmbito desse incessante combate Terra-mundo que é a circunstância primordial e fundadora de nossa própria existência terrestre: “Tudo só pode existir se for fundado. A realidade do rio, da montanha, da Terra não é uma realidade subsistente, mas validada, instituída" (DARDEL, 2011, p. 58 - destaque do autor).

Dardel (2011) chama atenção que trazer à luz não pode ser confundido com aquilo que o iluminismo pregava. Não se trata se recorrer a um excesso de racionalismo e objetividade para chegar a uma verdade sobre a terra. Ele alerta sobre o equívoco de pensar que a objetividade traria uma verdade absoluta. Para ele, uma visão puramente científica da terra traz o perigo de perda ou esquecimento daquilo que é mais essencial e fundamental. O cientificismo a vê apenas como matéria-prima, fonte e recurso. Neste sentido, a relação entre o homem e a terra deixaria de ser compreendida e o homem se perderia na insensatez da dominação, aniquilação e destruição justificados e legitimados cientificamente. Dardel afiram que há de se ter prudência, modéstia e sensatez para que o descobrir a terra não se transforme em sua desnaturalização e desacralização: "Um dos dramas do mundo contemporâneo é que a Terra foi "desnaturada", e o homem só pode vê-la através de suas medidas e de seus cálculos, em lugar de deixar-se decifrar sua escrita sóbria e vívida" (DARDEL, 2011, p. 96).

Diante de tal cenário, Dardel coloca a importância de não apegar-se excessivamente à geografia acadêmica nem entregar-se sem reservas à ciência. Antes, é preciso ponderar aquilo que está para além, uma geografia que se realiza na intimidade com a terra, a geografia 
do camponês, do montanhês, do pescador os quais "Em sua conduta e sua vida cotidiana, em sua sabedoria lacônica carregada de experiências, o homem manifesta que crê na Terra, que confia nela; que conta absolutamente com ela" (DARDEL, 2011, p. 93). Nesse sentido, o geógrafo chama atenção para o reconhecimento de um movimento de renovação, de um novo frescor da visão de resgatar o conhecimento no nível dos fenômenos, isto é, como o ser manifesto age sobre nossa sensibilidade e imaginação. Devemos nos lembrar de nossa relação visceral, existencial com a terra

Resistindo ao espírito do pensador que, em nome de uma razão muito rígida e muito imperiosa, entorpece nossa liberdade espiritual, salvaguardamos, com a poesia ou simplesmente com um pensamento livre, a fonte em que se revigora sem cessar nosso conhecimento do mundo exterior. A vida se encarrega, apesar de todas nossas barreiras intelectuais e de todas as precauções de um positivismo de visão estreita, de restituir aos espaços terrestres seu frescor e sua glória, por pouco que aceitemos recebe-los como dom (DARDEL, 2011, p. 97).

\section{A GEOGRAFIA FENOMENOLÓGICA COMO CIÊNCIA EXISTENCIAL}

A obra O Homem e a Terra é, para a geografia contemporânea, um grande manancial de perspectivas instigantes para as reconstruções que buscamos realizar. Longe de ser uma obra descontextualizada de nosso tempo, ela responde de forma muito próxima a questões que nos são colocadas atualmente.

Este potencial heurístico pode ser pensado em três pontos, a partir daquilo que discutimos neste artigo:

1. A busca de construção de uma ciência existencial, na senda heideggeriana, é uma resposta ao fracasso da ciência moderna em tornar nossa vida com sentido e qualidade. $\mathrm{Na}$ contramão das abstrações e do esmagamento do sujeito (TOURAINE, 1994), a proposição de uma ciência existencial permite pensar de forma mais modesta e prática o papel do cientista e do próprio conhecimento geográfico. Uma geografia construída sobre estas bases permite responder de forma mais plena as inquietações que moveram geógrafos em busca de outras bases para sua ciência desde os anos 1970. Uma geografia vivida em ato seria, portanto, compreender a dimensão existencial do próprio conhecimento geográfico e seu papel em nossa própria experiência cotidiana diária;

2. Uma geografia construída a partir ou em diálogo com a ontologia heideggeriana permite a construção de outra ontologia da geografia (HOLZER, 2010b; DAL GALLO, 2015). Outros geógrafos têm bebido do filósofo para pensar o sentido e a natureza da realidade geográfica, ajudando a construir uma geografia existencial, com o foco nos modos geográficos de existência (RELPH, 1985; PICKLES, 1985; MARANDOLA JR., 2012; 2014). Este projeto não implica a construção de um paradigma, mas uma abertura 
(ou aberturas) para pensar a geografia como dimensão da existência. Ela também se desdobra como poética do habitar, tema não explorado neste artigo, mas que se liga diretamente a esta proposição; na geografia e para além dela (SARAMAGO, 2008; NOGUERA; PINEDA, 2013; NOGUERIA; BERNAL, 2014; MARANDOLA JR., 2014);

3. A proposição de terra que Dardel desenvolve em seu ensaio permite repensar o fundamento da realidade geográfica, especialmente no que tange à tradição das relações homem-terra ou sociedade-natureza (PATTISON, 1977). O sentido de terra trazido da filosofia heideggeriana permite repensaras relações de um ponto de vista mais poético (no sentido de formas de existência), buscando outra base para compreendermos nossa existência a partir de nossa condição terrestre. A crise ambiental, amplamente discutida e preocupante atualmente, no contexto da globalização, reclama este refundar, e Dardel apresenta um caminho potente de pensamento para dar resposta à crise, que é a nossa própria crise (LEFF, 2001).

Contudo, ainda existe muito a ser explorado nessa relação entre Heidegger e Dardel. Há muitas entradas na obra do geógrafo da ontologia proposta pelo filósofo. Mesmo os três pontos elencados acima são aberturas, possibilidades de caminho que se abrem no exame mais detido daquilo que subjaz ou que constitui o fundamento do pensar dardeliano.

A apropriação do conceito de terra em Dardel, por exemplo, necessita de um cuidado e um esforço concentrado para desembaraçar os inúmeros nexos que ela envolve. Esse texto é uma primeira investida nesta direção, partindo de uma contextualização e caminhando para indícios e indicações dos nexos da leitura de Dardel sobre o conceito de Terra heideggeriano.

Dardel se dedica amplamente à discussão sobre a terra, seja quando faz a sua fenomenologia do espaço e explora suas diferentes dimensões, o aéreo, o aquático, o construído e o telúrico. Cada uma dessas dimensões por si só já apresenta uma densidade conceitual e referencial que necessita de uma atenção especial para serem compreendidas em toda a sua potencialidade.

Por outro lado, existe ainda a discussão de Dardel tratando da "história da Geografia", permeada sem dúvida pelo seu próprio senso de historicidade, que traz em princípio a Geografia Mítica que caracteriza-se por um relacionamento homem-terra sem tantas intermediações como em nossa época moderna. Aliás, sua perspectiva de história ainda está por ser estudada e colocada vis-à-vis com sua perspectiva geográfica. Esta ainda precisa ser resgatada de sua primeira obra, também publicada na Nouvelle Encyclopédie Philosophique, seis anos antes de O homem e a terra: História, ciência do concreto (DARDEL, 1946b) também apresenta uma constituição fenomenológica com forte influência do a pensamento de Heidegger. 
Por outro lado, a edição do volume Ecrits d'un monde entier (DARDEL, 2014) levanta outra ordem de questões, além do texto inédito L'appel du monde, onde a questão dos mitos e a estética da existência são tematizados, há um contexto atual de pesquisa que motivou, no mundo francófono não francês, esta edição fora do contexto dos estudos fenomenológicos, mais próximos das preocupações com a própria história, os mitos e especialmente a poética. Este parece ser um novo campo de interesse onde as ideias de Dardel estão frutificando, e precisa ser melhor compreendido e explorado.

A terra é uma presença sagrada, ela é, sem dúvida, o início e o fim de tudo. Essa é uma presença que Dardel deseja resgatar e o mito ou a discussão sobre os mitos e os poemas épicos tem fundamental importância para esse resgate. Aqui encontramos outra possível porta de entrada para compreender a influência do pensamento heideggeriano em Dardel, que precisa, sem dúvida, ser explorada.

A compreensão fenomenológica da terra, portanto, é um fundamentos da geografia proposta por Dardel. A tônica, influenciado pela ontologia heideggeriana, é o resgate do terrestre, como forma de reatar os laços perdidos em nossa existência como seres terrestres. Por isso determo-nos nessa sua leitura é um importante passo para a elucidação de sua proposta de construir uma geografia fenomenológica, de retorno às coisas mesmas tratando os próprios fenômenos como a fonte primeira do conhecimento geográfico.

A geografia para Dardel está implicada na existência humana, em uma relação existencial que deve ser reconhecida em sua dimensão teórica, mas, sobretudo, na sua dimensão ontológica que fundamenta o conhecimento

\footnotetext{
É necessário, portanto, compreender a geografia não como um quadro fechado em que os homens se deixam observar tal qual os insetos de um terrário, mas como o meio pelo qual o homem realiza sua existência, enquanto a Terra é uma possibilidade essencial de seu destino. (DARDEL, 2011, p.89)
}

Este é um dos caminhos para construção de uma geografia fenomenológica, tal como reivindicado pela geografia contemporânea, em sintonia com as questões mais prementes da contemporaneidade. Uma geografia fenomenológica, na direção apontada por Dardel, como ciência existencial, não é um novo paradigma para geografia. Trata-se de um movimento de religação com o sentido fundante da própria geografia, como elo do homem com a terra: nossa realidade existencial terrestre. 


\section{REFERÊNCIAS}

4. ALES BELO, Angela. A fenomenologia do ser humano. Trad. Antonio Angonese. Bauru: Edusc, 2000.

5. BARRETO, S. Ontologia e Crítica da metafísica: Kant e Heidegger. Revista Estudos Filosóficos, n. 8, p. 1-32, 2012.

6. BESSE, Jean-Marc. Ver a Terra: seis ensaios sobre a paisagem e a geografia. São Paulo: Perspectiva, 2006.

7. ___ Geografia e Existência: a partir da obra de Éric Dardel. In: DARDEL, Éric. O Homem e a Terra: natureza da realidade geográfica. São Paulo: Perspectiva, 2011. p. 111-140.

8. BIEMEL, Walter. Elucidações acerca da conferência de Heidegger A origem da obra de arte e a destinação do pensamento. O que nos faz pensar, v.2, n.1, 1996, p. 5-23.

9. BROSSEAU, Marc. Geography's Literature. Progress in Human Geography, v.18, n.3, p.333-353, 1994.

10. CHOLLIER, Alexandre; WADDELL, Éric. Vers une pensée du monde. In: Dardel, Éric. Ecrits d'um monde entier. Genève : Héros-Limite, 2014. p.11-27.

11. DAL GALLO, Priscila M. A ontologia da Geografia à luz da obra de arte: o embate Terramundo em Out of Africa. 2015. 93 f. Dissertação (Mestrado em Geografia) - Instituto de Geociências da Universidade Estadual de Campinas, Campinas, 2015.

12. DARDEL, Éric. La Pêche harenguière em France, des origines à nos jours : étude d'histoire économique et sociale. Paris: André Tournon et Cie, 1941a. (Tese principal de doutorado)

13. .État des peches maritimes sur les côtes occidentales de la France au début du XVIII ${ }^{\mathrm{e}}$ siècle. Paris : André Tournon et Cie, 1941b. (Tese complementar de doutorado)

14. . L'Histoire, ciencia du concret. Paris: Presses Universitaires de France, 1946a.

15. . Les peches maritimes. Paris : PUF, $1946 \mathrm{~b}$.

16. L_L_Homme et la Terre : nature de la réalité geographique. Paris : Presses Universitaires de France, 1952.

17. . L'Histoire et notre temps. Diogène, n. 21, 1958.

18. ___ L’uomo e la terra : natura della realitá geográfica. Milão: Unicopli, 1986.

19. ___ L_Homme et la Terre : nature de la réalité geographique. $2^{\circ}$ Edição. Paris : Editions du Comité des Travaux Historiques et Scientifiques, 1990.

20. . O Homem e a Terra: natureza da realidade geográfica. São Paulo: Perspectiva, 2011.

21. El Hombre y la Tierra: naturaleza de la realidad geográfica. Madrid: Biblioteca Nueva, 2013.

22 . Ecrits d'um monde entier. Genève : Héros-Limite, 2014.

23. DARDEL, Jacques. Éric Dardel, biographie. In: DARDEL, Éric. Ecrits d'um monde entier. Genève : Héros-Limite, 2014. p.28-32. 
24. HEIDEGGER, Martin. Introdução à Filosofia. Tradução Marco Antonio Cassanova. São Paulo: WMF Matins Fontes, 2009a.

25. __ O meu caminho na fenomenologia. Tradução Ana Falcato. Covilhã: Lusofia Press, 2009b.

26. ___ . A origem da obra de arte. In: ___ Caminhos de Floresta. Tradução Irene BorgesDuarte. Santa Maria da Feira: Fundação Calouste Gulbenkian, 2012a. p. 5-94.

27. Ser e tempo. Trad. Fausto Castilho. Campinas: Ed. da UNICAMP, 2012b.

28. Ciência e pensamento do sentido. In: HEIDEGGER, M. Ensaios e conferências. Trad. Emamanuel C. Leão. Petrópolis: Vozes; Bragança Paulista: Editora Universitária São Francisco, 2012c, p. 39-60.

29. HOLZER, Werther. A Geografia Humanista Anglo-Saxônica - de suas origens aos anos 90. Revistas Brasileira de Geografia, v. 55, n. ${ }_{114}$, p. 109-146, 1993.

30. _. A influência de Éric Dardel na construção da geografia humanista norte americana. In: ENCONTRO NACIONAL DOS GEÓGRAFOS, 16, 2010, Porto Alegre. Anais. Porto Alegre: AGB, 2010a.

31. ____. A construção de uma outra ontologia geográfica: a contribuição de Heidegger. Geografia, Rio Claro, v. 35, p. 241-251, 2010 b.

32. ___ A Geografia Fenomenológica de Éric Dardel. In: DARDEL, Éric. O Homem e a Terra: natureza da realidade geográfica. São Paulo: Perspectiva, 2011.p. 141-154.

33. HUSSERL, Edmund. A crise das ciências europeias e a fenomenologia transcendental: uma introdução à filosofia fenomenológica. Rio de Janeiro: Forense Universitária, 2012.

34. LEFF, Enrique. Epistemologia ambiental. São Paulo: Cortez, 2001.

35. LÉVY, Bertrand. Hommage à Dardel : au sujet de quelques sources philosophiques et littéraires de L'Homme et la Terre. Cahiers de géopoétique, v. 5, p. 29-39, 1996.

36. MALPAS, Jeff. Heidegger's topology: being, place, world. Cambridge: MIT Press, 2008.

37. MARANDOLA JR., Eduardo. Arqueologia fenomenológica: em busca da experiência. Terra Livre, São Paulo, v. 2, n.25, p. 67-79, 2005.

38. __ Prefácio à edição brasileira. In: DARDEL, Éric. O Homem e a Terra: natureza da realidade geográfica. (Trad. Werther Holzer) São Paulo: Perspectiva, 2011. p. xi-xiv.

39. Heidegger e o pensamento fenomenológico em Geografia: sobre os modos geográficos de existência. Geografia, Rio Claro, v. 37, p. 81-94, 2012.

40. ___ Fenomenologia e pós-fenomenologia: alternâncias e projeções do fazer geográfico humanista na geografia contemporânea. Geograficidade, v. 3, p. 49-64, 2013.

41. __ Habitar em risco: mobilidade e vulnerabilidade na experiência contemporânea. São Paulo: Blucher, 2014.

42. MARANDOLA JR., Eduardo; GRATÃO, Lúcia H. B. Do sonho à memória: Livia de Oliveira e a Geografia Humanista no Brasil. Geografia, Londrina, v. 12, n.2, p. 4-19, 2003. 
43. NOGUE, Joan. Presentación. In: DARDEL, Éric. El hombre y la tierra: naturaleza de la realidad geográfica. (Trad. María Beneyto) Madrid: Biblioteca Nueva, 2013.

44. NOGUERA, Ana P.; PINEDA, Jaime. Cuerpo-Tierra: epojé, disolución humano-naturaleza y nuevas geografías-sur. Geograficidade, v.4, n.1, p.20-29, 2014.

45. NOGUERA, Ana P.; BERNAL, Diana A. Geografias del habitar: um habitar geopoético em la era planetária. Geograficidade, v.4, n.2, p.19-31, 2014.

46. PATTISON, W. D. As quatro tradições da geografia. Boletim de Geografia Teorética, Rio Claro, v.7, n.13, p.101-10, 1977.

47. PICKLES, J. Phenomenology, Science and Geography: Spatiality and the Human Sciences. Cambridge University Press: New York, 1985.

48. PINCHEMEL, Philippie. Biografia de Éric Dardel. In: DARDEL, Éric. O Homem e a Terra: natureza da realidade geográfica. São Paulo: Perspectiva, 2011.p. 155-159.

49. RAFFESTIN, Claude. Pourquoi n'avons-nous pas lu Éric Dardel? Cahiers de géographie du Québec, v. 31, n. 84, p. 471- 481, 1987.

50. RELPH, Edward. Place and placelessness. London: Pilon, 1976.

51. RELPH, Edward. Geographical Experiences and Being-in-the-World. In: SEAMON, David; MUGERAUER, R. (Eds.) Dwelling, Place and Environment: Towards a Phenomenology of Person and World. New York: Columbia University Press, 1985.

52. SARAMAGO, Ligia. Topologia do ser: lugar, espaço e linguagem em Martin Heidegger. Rio de Janeiro: Loyola; PUC-Rio, 2008.

53. SANGUIN, André-Louis. La géographie humaniste ou l’approuche phénoménologique des lieux, des paysages et des espaces. Annales de Géographie, v.90, n.501, p.560-587, 1981.

54. SILVA, J. da O. Heidegger e Kant: o projeto ontológico de Ser e Tempo e a interpretação fenomenológica da Crítica da Razão Pura. 2013. 106 f. Dissertação (Mestrado em Filosofia) Universidade Federal de Santa Maria, Centro de Ciências Sociais e Humanas, Santa Maria-RS, 2013.

55. TOURAINE, Alain. Crítica da modernidade. Petropolis: Vozes, 1994.

56. WRIGHT, J. K. Terrae incognitae: the place of the imagination in Geography. Annals of the Association of American Geographers, v.37, p.01-15, 1947.

57. _. Terrae incognitae: o lugar da imaginação na Geografia. Geograficidade, v. 4, n. 2, p. 4-18, 2014.

Artigo recebido em $1^{\circ}$ de dezembro de 2015.

Artigo aceito em 20 de dezembro de 2015. 